LINGUODIDACTICA XXII

DOI: $10.15290 /$ lingdid.2018.22.04

\author{
mgr Ewelina Jasińska-Grabowska \\ Katolicki Uniwersytet Lubelski Jana Pawła II \\ Wydział Nauk Humanistycznych, Instytut Filologii Słowiańskiej \\ tel. 518978594 \\ e-mail: ewel.jgrabowska@gmail.com
}

ORCID ID: https://orcid.org/0000-0002-4881-4826

\title{
TECHNIKI TŁUMACZENIOWE TERMINOLOGII WETERYNARYJNEJ W ROSYJSKO-POLSKIM PRZEKŁADZIE SPECJALISTYCZNYM
}

\section{STRESZCZENIE}

Przedmiotem analizy w niniejszym artykule są rosyjskie terminy z dziedziny weterynarii dotyczące nominacji chorób zwierzęcych. Celem niniejszego artykułu jest charakterystyka semantyczna rosyjskiej terminologii weterynaryjnej, opis technik tłumaczeniowych zastosowanych przez tłumacza w przekładzie nazw chorób zwierząt oraz próba oceny trafności doboru tych technik. Uwagę skupiono na analizie dwutekstów - oryginalnego i przekładu na język polski, co pozwoliło wyekscerpować interesujący materiał badawczy oraz ocenić trafność zaproponowanych ekwiwalentów. Wyniki badań pokazały, że w danym typie tekstu najpopularniejszym sposobem przekładu okazała się technika uznanego odpowiednika. Stosowanie innych technik tłumaczeniowych okazało się zgubne i prowadziło do zatarcia znaczenia danej nazwy choroby bądź do jej zdeformowania.

Słowa kluczowe: terminologia, techniki tłumaczeniowe, przekład specjalistyczny, weterynaria

\section{SUMMARY}

TRANSLATION TECHNIQUES OF THE VETERINARY TERMINOLOGY IN THE RUSSIAN-POLISH SPECIALIST TRANSLATION

This article focuses on the analysis Russian terms in the veterinary field regarding the name of animal diseases. The intention of the article is attempt to characterize Russian veterinary terminology in the context of customs law of semantics, present translations techniques used in the translation of animal disease names and to evaluate the techniques. The attention was focused on the analysis of the original texts and the translation into Polish.

Key words: terminology, specialist translation, veterinary, translation techniques 
Zwierzęta żywe oraz produkty pochodzenia zwierzęcego obejmowane zarówno procedurą eksportu jak i importu podlegają kontroli weterynaryjnej, która ma na celu ochronę bezpieczeństwa państwa przed rozprzestrzenieniem się patogenów infekcyjnych chorób zwierzęcych na terytorium kraju oraz ochronę zdrowotności zwierząt.

W Euroazjatyckiej Unii Gospodarczej kontrolę weterynaryjną sprawuje odpowiedni terenowy Zarząd Federalnej Służby ds. Nadzoru Weterynaryjnego i Fitosanitarnego. Wyżej wspomniany Zarząd w ramach kontroli weterynaryjnej kieruje się przepisami międzynarodowymi oraz ustawodawstwem Euroazjatyckiej Unii Gospodarczej. Decyzją Komisji Unii Celnej (obecnie Euroazjatyckiej Unii Gospodarczej) z dnia 16 czerwca 2010 roku nr 317 „O stosowaniu środków weterynaryjno-sanitarnych w Unii Celnej” (О применени ветеринарно- санитарных мер в таможенном союзе) zatwierdzono następujące dokumenty:

- Jednolity wykaz towarów podlegających kontroli weterynaryjnej (Единый перечень товаров, подлежащих ветеринарному контролью (надзору);

- Jednolite wymogi weterynaryjne (weterynaryjno-sanitarne) odnoszące się do towarów podlegających kontroli weterynaryjnej (nadzorowi weterynaryjnemu) (Единые ветеринарнысе (ветеринарно-санитарные) требования, предбявляемые к товарам, подлежащим ветеринарному контролью (надзору) );

- Reguły dotyczące jednolitego trybu przeprowadzania wspólnego sprawdzania obiektów i wyboru próbek towarów (produkcji) podlegających kontroli weterynaryjnej (nadzorowi weterynaryjnemu) (Положение о едином порядке проведения совместных проверок объектов и отбора проб товаров (продукиии), подлежащих ветеринарному контролью (надзору));

- Reguły dotyczące jednolitego trybu dokonywania kontroli weterynaryjnej na granicy celnej Unii Celnej i na terytorium celnym Unii Celnej (Положение о едином порядке осуществления ветеринарного контроля на таможенной границе таможенного союза и на таможенной территории таможенного союза).

Zgodnie z punktem 6.1. Reguł dotyczących jednolitego trybu wspólnego sprawdzania obiektów i wyboru próbek towarów (produkcji) podlegających kontroli weterynaryjnej (nadzorowi weterynaryjnemu), przywóz towarów 
podlegających kontroli weterynaryjnej na terytorium unii celnej dokonywany jest po uzyskaniu pozwolenia na wwóz towarów wydanego przez państwo na terytorium którego jest wprowadzany towar (Ввоз подконтрольных товаров на таможенную территорию таможенного союза осуществляется при наличи разрешения на ввоз, выданного Стороной, на территорию которой ввозится подконтрольный товар). Koniecznym jest także posiadanie świadectwa weterynaryjnego wydanego przez kompetentne organa, tj. powiatowego lekarza weterynarii w kraju pochodzenia towaru.

W przypadku wywozu towaru z terytorium Euroazjatyckiej Unii Gospodarczej eksporter jest zobowiązany do przestrzegania wymagań weterynaryjnych kraju importera (Экспортер обязан соблюдать требования ветеринарного законодательства странь-импортера).

W Polsce nad bezpieczeństwem zdrowia zwierząt i produktów pochodzenia zwierzęcego czuwa Inspekcja Weterynaryjna. Jest to wyspecjalizowana instytucja rządowa działająca na mocy Ustawy z dnia 29 stycznia 2004 roku (Dz. U. 2004 nr 33 poz. 287). Zadania Inspekcji Weterynaryjnej sprowadzają się do trzech obszarów działania: zwalczania, przeprowadzania i sprawowania nadzoru.

W ramach zwalczania wyróżnia się następujące zadania: zwalczanie chorób zakaźnych zwierząt oraz zapobieganie ich wystąpieniu, wykrycie i likwidowanie ognisk zapalnych, zwalczanie chorób zwierzęcych przenoszonych na człowieka, monitorowanie zakażeń zwierząt rzeźnych i produktów pochodzenia zwierzęcego.

$\mathrm{W}$ ramach przeprowadzania wydziela się kontrolę graniczną i kontrolę weterynaryjną w handlu, wywozie zwierząt i produktów pochodzenia zwierzęcego.

W ramach nadzoru wyodrębnia się nadzór nad bezpieczeństwem produktów pochodzenia zwierzęcego, wprowadzeniem na rynek zwierząt, wytworzeniem, obrotem i stosowaniem środków żywienia zwierząt, zdrowiem zwierząt przeznaczonych do rozrodu, jakością materiału biologicznego, obrotem wyrobami medycznymi przeznaczonymi dla zwierząt, produkcją pasz itp.

W Polsce, a zatem w Unii Europejskiej przywóz zwierząt na terytorium Unii Europejskiej reguluje Ustawa z dnia 11 marca 2004 roku „O ochronie zdrowia zwierząt oraz zwalczaniu chorób zakaźnych zwierząt”. Transport zwierząt musi odbywać się zgodnie $\mathrm{z}$ warunkami zawartymi w Rozporządzeniu Rady (WE) nr 1/2005 z dnia 22 grudnia 2004 roku w sprawie ochrony zwierząt podczas transportu i związanych z tym działań oraz zawierające dyrektywy 64/432/EWG i 93/119/WE oraz rozporządzenia (WE) nr 1255/97. Weterynaryjna kontrola graniczna zwierząt i produktów wprowadzanych z państw trzecich jest dokonywana zgodne z Ustawą z dnia 27 sierpnia 2003 roku 
o weterynaryjnej kontroli granicznej przez urzędowego lekarza weterynarii w granicznym posterunku kontroli.

Po omówieniu postaw prawnych dotyczących przestrzegania prawa $\mathrm{w}$ zakresie weterynarii w obu systemach prawnych należy przedstawić różnice wynikające ze struktury organizacyjnej instytucji czuwających nad przestrzeganiem przepisów.

Głównym organem federalnym sprawującym pieczę nad całokształtem kontroli weterynaryjnej jest Federalna Służba ds. Nadzoru Weterynaryjnego i Fitosanitarnego (Федеральная служба по ветеринарному и битосанитарному надзору -Россельхознадзор). Jednostkami terytorialnymi są Zarządy Federalnej Służby ds. Nadzoru Weterynaryjnego i Fitosanitarnego (Управления федеральной службы по ветеринарному и фитосанитарному надзору). Te z kolei dzielą się na następujące wydziały:

- Wydział nadzoru weterynaryjnego i granicznej kontroli weterynaryjnej na granicy państwowej (Отдел ветеринарного надзора и пограничного контроля на государственной границе);

- Wydzial kwarantannowej kontroli fitosanitarnej na granicy państwowej (Отдел карантинного фитосанитарного контроля на государственной границе);

- Wydział nadzoru fitosanitarnego (Отдел фитосанитарного надзора);

- Wydział nadzoru weterynaryjnego (Отдел ветеринарного надзора);

- Wydział nadzoru ziemskiego (Отдел земельного надзора).

W Polsce z kolei nad prawidłowościami w przepisach weterynaryjnych i fitosanitarnych czuwają dwie instytucje, $\mathrm{z}$ czego jedna jest państwową osobą prawną (Państwowa Inspekcja Ochrony Roślin i Nasiennictwa), a druga instytucją rządową (Inspekcja Weterynaryjna).

Jednostkami terytorialnymi Państwowej Inspekcji Ochrony Roślin i Nasiennictwa jest 16 wojewódzkich Inspekcji Ochrony Roślin i Nasiennictwa, których wewnętrzna organizacja wygląda następująco:

- Biuro Ochrony Upraw i Techniki;

- Biuro Nadzoru Fitosanitarnego;

- Biuro Nasiennictwa;

- Centralne Laboratorium w Toruniu;

- Biuro Dyrektora Generalnego.

Inspekcja Weterynaryjna strukturalnie prezentuje się następująco: Główny Inspektorat Weterynarii na czele z Głównym Lekarzem Weterynarii sprawuje kontrolę nad Wojewódzkim Inspektoratem Weterynarii na czele z Wojewódzkim Lekarzem Weterynarii oraz Granicznym Inspektoratem Weterynarii z Granicznym Lekarzem Weterynarii na czele. Wojewódzki Inspektorat Weterynarii 
kontroluje z kolei Powiatowy Inspektorat Weterynarii na czele z Powiatowym Lekarzem Weterynarii.

Z przedstawionej powyżej charakterystyki struktur obu systemów prawnych wynika, iż w polskim systemie prawnym w zakresie przepisów weterynaryjnych nie ma analogicznej instytucji, jaka funkcjonuje w rosyjskim systemie prawnym. Nad kontrolą weterynaryjną i fitosanitarną czuwa jedna instytucja. Natomiast w systemie polskim mamy pewnego rodzaju dualizm, tzn. za kontrolę fitosanitarną odpowiada odrębna instytucja, a za nadzór weterynaryjny inna.

Celem niniejszego artykułu jest charakterystyka semantyczna rosyjskiej terminologii weterynaryjnej, opis technik tłumaczeniowych zastosowanych przez tłumacza w przekładzie nazw chorób zwierząt oraz próba oceny trafności doboru tychże technik. Materiał badawczy do niniejszego artykułu został wyekscerpowany ze „Wspólnych wymogów weterynaryjnych (weterynaryjno-sanitarnych), odnoszacych się do towarów podlegających kontroli weterynaryjnej (nadzorowi weterynaryjnemu)" stanowiących załącznik do wspomnianej Decyzji Komisji Unii Celnej z dnia 18 czerwca 2010 roku nr 317. Powyższe wymogi mają zapewnić ochronę przestrzeni celnej Euroazjatyckiej Unii Gospodarczej przed wwozem i rozprzestrzenianiem patogenów infekcyjnych chorób zwierząt, w tym chorób wspólnych dla zwierząt i człowieka, jak również towarów. $\mathrm{Z}$ racji tego, iż wyekscerpowany materiał jest obszerny, $\mathrm{w}$ danym artykule zostaną omówione najbardziej reprezentatywne przykłady. W badaniach została zastosowana metoda porównawcza, tj. analiza dwutekstów - oryginalnego i przekładu na język polski - w celu określenia sposobów przekładu terminologii z zakresu weterynarii.

W przekładzie tekstów prawnych istotną rolę odgrywają: leksyka specjalistyczna, warstwa stylistyczna i składniowa oraz makrostruktura tekstu. W celu osiągnięcia zamierzonego celu komunikacyjnego tłumacz jest zobligowany do zastosowania właściwych technik.

W przypadku przekładu prawnego pojawia się problem wynikający z różnic $\mathrm{w}$ systemach prawnych, $\mathrm{z}$ którymi dane dwuteksty są powiązane. Tłumacze stosują różne metody, mające na celu optymalizację procesy takiego przekładu. Teoretycy przekładu z kolei od pewnego czasu dążą do klasyfikacji metod stosowanych przez tłumaczy. Jednakże do tej pory nie ma jednolitej klasyfikacji technik tłumaczeniowych odnoszących się stricte do tłumaczenia prawnego i prawniczego. Najbardziej znanymi klasyfikacjami metod tłumaczeniowych są propozycje J.P. Vinaya i J. Darbelneta (1958/2000), P. Newmarka (1988) i A. Chestermana (1997). Zanim jednak zostaną zaprezentowane powyższe klasyfikacje należy uściślić definicję techniki tłumaczeniowej.

J.P. Vinay i J. Darbelnet przedstawiają klasyfikację translation methods (metody tłumaczeniowe) i procedures (procedur), P. Newmark proponuje 
klasyfikację translation strategies (strategii tłumaczeniowych), a A. Chestermann translation strategies (strategii tłumaczeniowych). W niniejszej pracy przyjęto definicję techniki tłumaczeniowej za K. Hejwowskim: „wybór pewnego rozwiązania konkretnego problemu napotkanego w trakcie procesu tłumaczenia, wreszcie samo rozwiązanie tłumaczeniowe, które można bezpośrednio ocenić

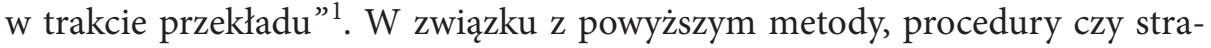
tegie zaproponowane przez wspomnianych wyżej badaczy będą w niniejszym artykule określane mianem technik tłumaczeniowych. Podejście takie wynika z tego, iż określenie strategia jest metodą stosowaną konsekwentnie na przestrzeni całego tekstu. W przypadku tekstów normatywnych tłumacz jest zmuszony w różnych fragmentach tekstu stosować zróżnicowane techniki przekładowe w celu osiągnięcia określonego celu komunikacyjnego.

J.P. Vinay i J. Darbelnet wyróżniają trzy bezpośrednie metody tłumaczenia: zapożyczenia, kalki, tłumaczenie dosłowne oraz cztery metody okrężne: transpozycję, modulację, ekwiwalencję i adaptację. Zapożyczenia mają zastosowanie wówczas, kiedy w języku docelowym nie można odnaleźć ekwiwalentu dla danej jednostki tekstu oryginału, ale również w celu osiągnięcia określonego efektu komunikacyjngo. Z kolei kalki polegają na dosłownym przekładzie elementów zapożyczonego wyrażenia. Dzieli się je na kalki leksykalne i kalki strukturalne. Definicja tłumaczenia dosłownego nie została precyzyjnie przedstawiona przez wspomnianych badaczy. Według nich jest to bezpośrednie przekształcenie tekstu oryginału w tekst przekładu przy zachowaniu reguł języka docelowego (zwłaszcza gramatyki i idiomatyki). Badacze zauważają, że zastosowanie owej techniki jest uzasadnione w przypadku języków pokrewnych. Transpozycja to zastąpienie wyrazu jednej klasy wyrazem z innej klasy przy zachowaniu znaczenia wypowiedzi. Z kolei modulacja to przekształcenie formy wypowiedzi polegające na zmianie punktu widzenia. Ekwiwalencja to zastąpienie terminu tekstu oryginału jego funkcjonalnym ekwiwalentem, który nie musi być podobny ani stylistycznie ani strukturalnie do terminu tekstu oryginału. Adaptacja jest stosowana, kiedy sytuacja opisywana w tekście oryginału nie jest znana w kulturze docelowej. Tłumacz wówczas tworzy sytuację, która może być uznana za ekwiwalentną. K. Hejwowski słusznie zauważa, iż dwie ostatnie techniki nie są zbyt trafne, ponieważ owe terminy są obecnie używane $\mathrm{w}$ innym znaczeniu ${ }^{2}$.

P. Newmark wyróżnia translations methods odnoszące się do całych tekstów oraz translations procedures dotyczące zdań i mniejszych jednostek języka. Wśród technik P. Newmark wyróżnia: tłumaczenie dosłowne, transferencję,

1 K. Hejwowski, Kognitywno-komunikacyjna teoria przekładu, Warszawa 2012, s. 76.

2 Ibidem, s. 75. 
naturalizację, ekwiwalent kulturowy, ekwiwalent funkcjonalny, ekwiwalent opisowy, synonimię, kalkę / zapożyczenie, transpozycję, modulację, uznane tłumaczenie, kompensację, analizę składnikową, redukcję i rozszerzenie, parafrazę, dublety tłumaczeniowe, przypisy, dodatki i objaśnienia ${ }^{3}$.

Tłumaczenie dosłowne jest podstawową techniką tłumaczeniową, ,jest właściwe i konieczne, jeśli zapewnia referencyjną i pragmatyczną ekwiwalencję w stosunku do oryginału” ${ }^{4}$. Badacz uważa, „że tłumaczenie dosłowne obejmuje tłumaczenie słowa za pomocą słowa, grupę słów za pomocą grupy słów, kolokacji za pomocą kolokacji oraz zdania za pomocą zdania. Dłuższe jednostki rzadko można przetłumaczyć z zastosowaniem owej techniki jeden do jednego" 5 . Transferencja to przeniesienie wyrazu z języka oryginału do tekstu języka przekładu. K. Hejwowski uważa, że jest to zapożyczenie ${ }^{6}$. Naturalizacja to technika, w wyniku której wyraz z tekstu źródłowego zostaje dostosowany do wymowy i pisowni języka przekładu. Ekwiwalent kulturowy to tłumaczenie przybliżone, gdzie słowo $\mathrm{z}$ języka oryginału nacechowane kulturowo zostaje przetłumaczone przy użyciu słowa z języka przekładu również nacechowanego kulturowo. Ekwiwalent funkcjonalny jest techniką stosowaną w przypadku słów specyficznych dla kultury docelowej, gdzie w przekładzie stosuje się wyraz neutralny kulturowo. Ekwiwalent opisowy ma na celu wyjaśnienie elementu charakterystycznego dla danej kultury. Przesunięcie to technika tłumaczeniowa dotycząca zmiany gramatycznej z języka oryginału na język przekładu. Pierwszy typ tego rodzaju zmiany dotyczy zmiany liczby (z pojedynczą na mnogą), drugi typ zmiany dotyczy struktury gramatycznej, natomiast trzeci typ zmiany występuje, gdy tłumaczenie dosłowne jest możliwe, ale nie współgra $\mathrm{z}$ naturalnym użyciem w języku docelowym, czwarty typ zmiany to zastąpienie luki leksykalnej strukturą gramatyczną. Technika uznanego tłumaczenia polega na używaniu oficjalnego i ogólnie uznanego terminu. Technika kompensacji występuje wówczas, kiedy znaczenie, metafora zostały pominięte w pewnej części zdania w języku przekładu, ale pojawiły się w innym miejscu. Technika analizy składnikowej to porównanie wyrazu o podobnym znaczeniu języka oryginału z wyrazem języka przekładu poprzez przedstawienie ich wspólnych i różniących cech pojęciowych. Zazwyczaj wyraz z języka oryginału ma węższe znaczenie niż wyraz z języka przekładu. Wówczas tłumacz dodaje elementy znaczeniowe aby zbliżyć znaczenie obu wyrazów ${ }^{7}$.

3 A. Kizińska, Ekwiwalencja w tłumaczeniu tekstów prawnych i prawniczych. Polskie i brytyjskie prawo spadkowe, Warszawa 2015, s. 34.

4 Ibidem, s. 34

Ibidem.

6 K. Hejwowski, Kognitywno-komunikacyjna teoria przekładu..., op. cit., s. 75.

A. Kizińska, Ekwiwalencja w tłumaczeniu tekstów prawnych..., op. cit., s. 34-36. 
A. Chestermann wyodrębnił trzy główne rodzaje technik tłumaczeniowych: syntaktyczne/gramatyczne, semantyczne i pragmatyczne.

Wśród technik syntaktycznych badacz wydzielił: tłumaczenie dosłowne, zapożyczenie/kalka, transpozycja, przesunięcie jednostki, zmiana struktury formy, zmiana struktury zdania składowego, zmiana struktury zdania, zmiana spójności, przesunięcie poziomu, zmiana schematu ${ }^{8}$.

Tłumaczenie dosłowne badacz definiuje jako „znaczenie maksymalnie bliskie formie języka źródłowego, ale poprawne gramatycznie" „obejmuje zapożyczenie oddzielnej jednostki jak i syntagmy ${ }^{10}$. Transpozycja to każda zmiana klasy wyrazu obejmująca zmianę struktury. Technika przesunięcia jednostki dotyczy zmiany jednostki tekstu oryginału na inną jednostkę, gdzie jednostkami są morfem, słowo, fraza, zdanie składowe, akapit. Zmiana struktury formy sprowadza się do wielu zmian na poziomie frazy np. zmiana liczby we frazie rzeczownikowej czy osoby lub czasu we frazie czasownikowej. Zmiana struktury zdania składowego dotyczy wprowadzenia zmian w strukturę zdania składowego i wpływa na jednostki zdania np. zdanie nadrzędne staje się zdaniem podrzędnym. Technika zmiany spójności polega na tym, że „coś wpływa na referencję wewnątrz tekstu, elipsę, podstawienie, wprowadzenie zaimków oraz powtórzenia lub użycie rodzaju łączników" ${ }^{\prime 1}$. W technice przesunięcia poziomu, sposób wyrażenia danej jednostki zostaje przesunięty na inny poziom: fonologiczny, morfologiczny, składniowy bądź leksykalny. Technika zmiany schematu odnosi się do zmian wprowadzanych w schematy retoryczne, np. powtórzeń ${ }^{12}$.

Badacz wśród technik semantycznych wyróżnił: synonimię, antonimię, hiponimię, konwersję, przesunięcie poziomu abstrakcji, zmianę rozmieszczenia, zmianę emfazy, parafrazę, zmianę tropu.

Synonimia to wybór synonimu lub bliskiego synonimu zamiast ekwiwalentu. Antonimia dotyczy wyboru antonimu i użycia go z przeczeniem. Technika hiponimii obejmuje następujące przypadki: zastąpienie hiperonimu obecnego w tekście oryginału hiponimem w tekście przekładu; zastąpienie hiponimu w tekście oryginału hiperonimem w tekście przekładu; zastąpienie hiponimu $\mathrm{X}$ w tekście oryginału hiponimem Y (hiperonimu, który mógłby być użyty w tekście przekładu). Konwersja jest definiowana przeważnie jako pary struktur

Ibidem, s. 36-37.

9 Ibidem, s. 36.

10 Ibidem, s. 37.

11 Ibidem.

12 Ibidem. 
czasownikowych dotyczących tego samego stanu rzeczy ale z przeciwstawnych punktów widzenia np. kupić - sprzedać. Technika zmiany poziomu abstrakcji polega na zastąpieniu jednostki tekstu oryginału jednostką o znaczeniu mniej lub bardziej abstrakcyjnym. Technika zmiany rozmieszczenia polega na zmianie rozmieszczenia tych samych komponentów syntaktycznych za pomocą większej liczby jednostek leksykalnych (ekspansja) lub mniejszej (kompresja). Za pomocą techniki emfazy dodaje się, redukuje lub przenosi nacisk tematyczny. Technika parafrazy sprawia, że przekład może być luźny lub „niedotłumaczony”. Technikę zmiany tropu stosuje się w przypadku tropów retorycznych ${ }^{13}$.

Wśród technik pragmatycznych A. Chestermann wyróżnił: filtrowanie kulturowe, zmianę jednoznaczności, zmianę informacji, zmianę interpersonalną, zmianę illokucyjną, zmianę spójności, tłumaczenie częściowe, zmianę widoczności, przeredagowane, inne zmiany pragmatyczne.

Technika filtrowania kulturowego jest znana także pod pojęciem naturalizacja bądź adaptacja i polega na tłumaczeniu tekstu nacechowanego kulturowo za pomocą ekwiwalentów obecnych w języku przekładu, które także są nacechowane kulturowo. Technika zmiany jednoznaczności polega na przetłumaczeniu elementów niejednoznacznych zawartych w tekście oryginału za pomocą elementów jednoznacznych bądź odwrotnie. Technika zmiany informacji dotyczy dodania nowej istotnej informacji w tekście przekładu mającej znaczenie dla odbiorcy w języku przekładu a nieobecnej w tekście oryginału lub odwrotnie. Zmiana interpersonalna zachodzi na poziomie stylu, zmianie poziomu formalności, emocjonalności. Zmiana illokucyjna dotyczy zmiany aktu mowy np. trybu czasownika. Zmiana spójności dotyczy z kolei zmiany logicznego przedstawiania informacji w tekście (pojęć). Zmiana widoczności odnosi się do jawnej obecności tłumacza w tekście np. w postaci przypisów czy komentarzy w nawiasach ${ }^{14}$.

Wartą przytoczenia jest także klasyfikacja technik tłumaczeniowych niemieckiego badacza M. Schreibera według czterech konkretnych kryteriów tj. płaszczyzny leksykalnej, gramatycznej i semantycznej oraz procedury pomocnicze np. przypisy, komentarze czy posłowia tłumacza.

$\mathrm{Na}$ płaszczyźnie leksykalnej badacz wyodrębnił następujące techniki.

Zapożyczenie leksykalne rozumiane jako przejęcie jednostki leksykalnej z języka oryginału do języka przekładu jako obcej bez odpowiedniego dostosowania lub z dostosowaniem formy do reguł ortograficznych, fonologicznych

13 A. Kizińska, Ekwiwalencja w tłumaczeniu tekstów prawnych..., op. cit., s. 37-38.

14 Ibidem, s. 38-39. 
lub morfologicznych języka przekładu. Drugi rodzaj zapożyczenia leksykalnego dotyczy przejęcia leksemu przez język oryginału i język przekładu z języka trzeciego. Substytucja leksykalna polega na zastąpieniu jednostki leksykalnej z języka oryginału jednostką leksykalną języka przekładu w odniesieniu do pojedynczego wyrazu lub grupy wyrazowej. Modyfikacja struktury leksykalnej zawiera się w zmianie słowotwórczej ${ }^{15}$.

Na płaszczyźnie gramatycznej badacz wyodrębnił następujące techniki.

Tłumaczenie słowo $\mathrm{w}$ słowo polega na zachowaniu w języku przekładu szyku, liczby, części mowy, konstrukcji syntaktycznej typowej dla języka oryginału. Permutacja to technika polegająca na zmianie szyku wyrazów lub szyku w obrębie grupy wyrazowej. Ekspansja to zwiększenie ilości słów w translacie. Przeciwstawną techniką jest redukcja czyli zmniejszenie ilości słów w translacie. Zmiana intrakategorialna polega na zmianie charakterystyki gramatycznej w obrębie tej samej części mowy np. zmiana liczby. Transpozycja to zmiana kategorii gramatycznej w translacie ${ }^{16}$.

Na płaszczyźnie semantycznej badacz wyróżnił cztery techniki.

Zapożyczenie semantyczne polegają na werbalizacji tych samych cech treści zawartych $\mathrm{w}$ jednostce $\mathrm{z}$ języka oryginału. Modulacja to zmiana perspektywy dzięki werbalizacji innych cech treści. Eksplikacja to zwiększenie stopnia wyeksponowania dzięki bardziej precyzyjnemu wyrażeniu treści w translacie. Przeciwstawną techniką jest implikacja polegająca na zmniejszeniu stopnia wyeksponowania za pomocą mniej precyzyjnego wyrażenia treści w translacie ${ }^{17}$.

Ostatnią klasyfikacją istotną w polskiej teorii przekładu jest podział wspomnianego już K. Hejwowskiego, który wyodrębnił dziewięć technik tłumaczeniowych. Pierwszą z nich jest reprodukcja bez objaśnień polegająca na użyciu w tekście przekładu niezasymilowanego słowa lub wyrażenia użytego w tekście oryginału. Badacz celowo wprowadza taką technikę nie używając terminu transfer lub zapożyczenie. Według badacza zapożyczenie nie może być techniką tłumaczeniową, gdyż opisuje zjawisko słowotwórcze. Reprodukcja niekiedy może obejmować pewne zmiany ortograficzne (naturalizacja P. Newmarka) lub transliterację jeśli tłumacz ma do czynienia z różnymi alfabetami. Przeciwstawną techniką jest reprodukcja z objaśnieniami, która pozwala odbiorcy zrekonstruować odpowiednie schematy, scenariusze czy sceny ${ }^{18}$. Tłumaczenie

15 A.D. Kubacki, Jak tlumaczyć oficjalne nazwy zawodów i specjalności z języka niemieckiego i na język niemiecki?, [w:] Język a komunikacja 26. Tłumacz wobec problemów kulturowych, M. Piotrowska (red.), Kraków 2010, s. 73-74.

16 Ibidem, s. 74-75.

17 Ibidem, s. 75-76.

18 K. Hejwowski, Kognitywno-komunikacyjna teoria przekładu..., op. cit., s. 77-78. 
syntagmatyczne bez objaśnień jest z kolei na tyle niebezpieczne, że ukrywa czasem głębszy sens danego sformułowania lub jego znaczenie w kulturze wyjściowej. Tłumaczenie syntagmatyczne z objaśnieniami (w postaci przypisu lub krótkiego komentarza) jest dobrym rozwiązaniem, jeśli objaśnienie jest jasne i zgodne z prawdą ${ }^{19}$. Uznany ekwiwalent, rozumiany przez K. Hejwowskiego jako element kultury wyjściowej funkcjonującej w języku docelowym, jest podstawową techniką w przypadku tłumaczenia „nazw instytucji, organizacji itp., niektórych nazw geograficznych i nielicznych nazwisk"20. Ekwiwalent funkcjonalny polega na „zastąpieniu nazwy zjawiska lepiej znanego w kulturze wyjściowej nazwą zjawiska lepiej znanego w kulturze docelowej" ${ }^{21}$. Technika ta jest godna polecenia w sytuacji, kiedy rzeczywiście nie można znaleźć bliskiego ekwiwalentu, a rola danej jednostki jest istotna w tekście ${ }^{22}$. Technika hiperonimu, według badacza, jest techniką ryzykowną, gdyż zazwyczaj gubi jakiś element kultury wyjściowej. Jednakże użycie tej techniki jest uzasadnione w przypadku gdy w języku przekładu nie istnieje utrwalony ekwiwalent danej jednostki języka oryginału, a jednostka ta nie odgrywa istotnej roli w tekście oraz gdyby inne techniki tłumaczeniowe okazały się zgubne ${ }^{23}$. W przypadku techniki ekwiwalentu opisowego "podstawia się opis czy też definicję za termin i w związku z tym może być zastosowana tylko wtedy, gdy dany element pojawia się w tekście raz i nie odgrywa w nim bardzo znaczącej roli”24. Opuszczenie według badacza jest techniką ostateczną ${ }^{25}$.

Żadna z przedstawionych klasyfikacji technik tłumaczeniowych nie pretenduje do bycia idealną. Wydawać się by mogło, że klasyfikacja zaprezentowana przez niemieckiego badacza M. Schreibera jest najbardziej przejrzysta, gdyż grupuje techniki z uwzględnieniem określonych poziomów języka i mogłaby być wykorzystana przy analizie tekstów prawnych. Należy jednak zauważyć, iż wybór techniki tłumaczeniowej jest uzależniony od typu tekstu. W tekstach użytkowych i specjalistycznych, tym samym prawnych i prawniczych dominować będzie np. technika uznanego ekwiwalentu, ekwiwalentu funkcjonalnego, ekwiwalentu opisowego czy hiperonimu. Z kolei w tekstach literackich, gdzie cel komunikacyjny jest całkiem inny, z pewnością mogą być stosowane techniki pragmatyczne lub syntagmatyczne.

19 Ibidem, s. 78-79.

20 Ibidem, s. 79.

21 Ibidem, s. 80-81.

22 Ibidem, s. 81.

23 Ibidem, s. 82.

24 Ibidem.

25 Ibidem, s. 82-83. 
Zanim zostaną przedstawione przykłady wybranych technik zastosowanych przez tłumacza warto przyjrzeć się krótkiej charakterystyce semantycznej danej terminologii w analizowanym akcie prawnym. Jak już było wspomniane, terminologia weterynaryjna $\mathrm{w}$ danym artykule jest analizowana $\mathrm{w}$ odniesieniu do prawa celnego. Przepisy prawa celnego także regulują zasady przywozu i wywozu zwierząt żywych, ich części, produktów pochodzenia zwierzęcego, a także roślin i produktów pochodzenia roślinnego. W przypadku wwozu na teren Unii Europejskiej zwierzęta powinny znajdować się na listach ogłaszanych przez Komisję Europejską. Powinny także spełniać określone wymagania zdrowotne określone przez przepisy adekwatne do danego gatunku zwierząt i powinny dotyczyć np. stanu zdrowia, gospodarstw lub innych miejsc przetrzymywania zwierząt oraz stad i obszarów, z których takie zwierzęta pochodzą, przeprowadzenia kwarantanny, środków transportu i warunków transportowania zwierząt. Zwierzę może zostać niedopuszczone do wwozu przez granicznego lekarza weterynarii, jeśli nie spełnia określonych przepisami wymagań. W przypadku roślin, ich wprowadzenie na terytorium Unii Europejskiej zachodzi po przeprowadzeniu granicznej kontroli fitosanitarnej, która obejmuje czynności sprawdzające dotyczące wymaganych dokumentów, tożsamości i zdrowotności roślin. Do momentu zakończenia takiej kontroli produkty tego typu znajdują się pod nadzorem organu celnego.

Terminy związane $\mathrm{z}$ weterynarią można zatem rozdzielić na następujące grupy:

A. Rodzaje zwierząt ze względu na przeznaczenie, np.: Экспериментальные животные, продуктивные животные, карантинированные животные, племенный крупный рогатый скот, пользовательный крупный рогатый скот, быки-производители, коровы-доноры эмбрионов.

B. Gatunki zwierząt:

- Ptaki np.: индюшата, утята, гусята, страусята;

- Ssaki np.: крупные парнокопытные, крупный рогатый скот, зубры, буйвол, зебра, як, антилопа, жираф;

- Owady nр.: медоносные пчель, шмели, люиерновые пчельлисторезь, пчель-кукушки, имелиные/пчелиные семьи.

C. Substancje biologiczne nр.: сперма быков-производителей, сперма баранов, сперма козлов-производителей, сперма хряков, сперма племенных жеребиов, фитотоксины, яичный порочок, меланж, альбумина, антитела.

D. Inne substancje chemiczne np.: натуральнье/синтетические эстрогенные/гормональные вещества, тиреостатические препараты, 
красящие вещества, тяжёлье металли, пестицидь, алдрин, ГЦХГ, DDT, метаболит, гептохлор, свинеи, кадмий.

E. Leki nр.: хлорамфеникол, хлорфармазин, колхицин, дапсон, диметридазол, нитрофураны, ронидазол, кумафос, амитраз.

F. Choroby:

1. Bakteryjne nр.: бруциелез, лептспироз, сибирская язва, трихомоноз, кампилобактериоз, хламидиоз (экзотический аборт), паратуберкулезный энтерит, каммилобактериоз, контагиозная плевропневмония крупного рогатого скота и мелкого рогатого скота, инфекиионный мастит, инфекизинныцй эпидидимит.

2. Wirusowe nр.: ящур, губкообразная энцеббалопатия крупного рогатого скота, контагиозная плевропневмония, везикулярный стоматит, блутанг, чума крупного рогатого скота, заказный узелковыц дерматит, туберкулёз, паратуберкулез, нфекиионный ринотрахеит, вирусная диарея крупного рогатого скота, меди-висна, нодулярный дермаmum.

3. Pasożytnicze nр.: заказныци узелковыци дерматит, трихинеллез, случная болезнь, сура, нутталиоза (бабезия Экви), пироплазмоза (бабезия Кабани), чеснока, инфекиионньй гидроперикардит, иистииеркоз, трипоносомоза (болезнь Чагаса), дерматофетоз.

4. Nowotworowe nр.: лейкоз, аденомотоза.

5. Zapalne nр.: артрит-эниеббалит.

G. Organizmy biologiczne:

1. Patogeny nр.: карантинные объекты в жизнеспособном состоянии, возбудители бактериальньх болезней, возбудители вирусных болезней, возбудители нематодных болезней, патогенный/токсикогенный микроорганизм, эмбрион крупного рогатого скота, возбудители группь энтеробактрий, патогенная фолора, энтеропатогенные эмерихии, карантинные вредные организмы.

2. Pasożyty nр.: эктопаразит, эндопаразит, личинки отводов, nаразиmbl.

H. Badania medyczne nр.: диагностические исследования, положительные реакиии, серологические/аллергические реакиии, термометрия, клиническиеисследования, микробиологическиепараметры, физикохемические показатели, химикотоксикологические показатели, радиологические показатели, органолептических показатели, 
полевые обследование, лабораторные обследование, сследование образиов подкарантинной продукиии.

Na podstawie wyżej przedstawionych grup semantycznych można zauważyć, iż rosyjska terminologia weterynaryjna należy do leksyki wysokospecjalistycznej. W związku z tym można by założyć, że w przypadku tłumaczenia tekstów z zakresu weterynarii, jak i medycyny tłumacz powinien stosować utrwalone odpowiedniki terminów mając na uwadze fakt, że zarówno weterynaria, jak i medycyna są dziedzinami nauki, które współcześnie rozwijają się niezwykle dynamicznie. Przedstawiona poniżej analiza nazw chorób zwierząt pozwoli zweryfikować powyższą hipotezę.

Jak już stwierdzono, w przypadku tłumaczenia nazw chorób zwierząt dominować powinna technika tzw. uznanego odpowiednika, aby zapobiec jakimkolwiek nieporozumieniom przy regulacji przepływu zwierząt przez granicę celną. Tymczasem w odniesieniu do całego badanego tekstu można zauważyć pewne błędy na płaszczyźnie tłumaczeniowej.

Ze 129 badanych jednostek terminologicznych napotkano jedną, dodajmy, nieudaną próbę zastosowania techniki ekwiwalentu funkcjonalnego. Przy przekładzie nazwy choroby bydła контагиозная плевропневмония zastosowano odpowiednik zaraza piersiowa koni. Zaproponowany ekwiwalent nie jest trafnym wyborem, ponieważ na wspomnianą zarazę piersiową koni mogą zachorować tylko konie, choroba nie jest przenoszona na inne gatunki zwierząt. W rozdziale 1., w którym zastosowano ten ekwiwalent, są wymieniane wyłącznie choroby dotyczące bydła rogatego. Powodem wprowadzenia w błąd mógł być także fakt, że prawodawca w oryginalnym tekście rosyjskim nie podał pełnego brzmienia choroby, tak jak to robi w innych fragmentach aktu np. контагиозная плевропневмония крупного и мелкого pогатого скота, gdzie wówczas stosowano technikę odpowiednika uznanego zaraza płucna bydła rogatego i małych przeżuwaczy. Zaraza piersiowa koni, zwana potocznie piersiówką, atakuje tylko konie w wieku od 3 do 9 lat i objawia się początkowo kilkudniową gorączką ok. 40,50 C, ogólnym osłabieniem, dreszczami, brakiem apetytu i dużym pragnieniem. Zwykle po 2-3 dniach pojawiają się objawy zapalenia płuc i opłucnej typu kaszel, duszności, wypływy śluzowo-ropne z nosa. Z kolei zaraza płucna bydła w Polsce obecnie nie występuje. Po okresie początkowym choroby tj. 2-4 tygodnie pojawia się kaszel, przyśpieszone oddechy, wzrost temperatury ciała, zmniejszony apetyt, spadek mleczności oraz spadek wagi.

Z powyższych charakterystyk wynika, że powyższe choroby mają całkiem inne podłoże i dotyczą innych gatunków zwierząt, dlatego też zastosowany 
ekwiwalent funkcjonalny nie jest $\mathrm{w}$ danym fragmencie akceptowalny, a termin powinien zostać przetłumaczony jako „zaraza płucna (bydła rogatego)”. Pytaniem bez odpowiedzi pozostaje fakt, czy ten przypadek wynika $\mathrm{z}$ braku wiedzy specjalistycznej tłumacza czy też był umyślnym zabiegiem zastosowania ekwiwalentu funkcjonalnego jednakże nieudanym i wprowadzającym w błąd.

Innym przykładem użycia techniki ekwiwalentu funkcjonalnego przy jednoczesnym funkcjonowaniu odpowiednika uznanego jest nazwa choroby Паратуберкулез przetłumaczona jako przerostowe zakaźne zapalenie jelit. W polskiej terminologii funkcjonuje odpowiednik wspomnianej choroby w formie Paratuberkuloza zwana inaczej jako choroba Johnego lub Paragruźlica. W wyniku analizy wykazano, iż zastosowany odpowiednik przerostowe zakaźne zapalenie jelit może być ekwiwalentem funkcjonalnym, gdyż Paratuberkuloza powoduje przewlekłe i wyniszczające przerostowe zapalenie jelit, ale nie jest to choroba stricte dotycząca wspomnianego objawu. Zapalenie jelit jest tylko wynikiem tejże choroby, podobnie jak anemia lub odwodnienie organizmu. U chorych zwierząt obserwuje się znaczny spadek mleczności, trudności z zacielaniem, ronienia upośledzonych płodów oraz zwiększoną podatność na zapalenie macicy. Częstym skutkiem choroby bywa także anemia. Można zatem stwierdzić, że zaproponowane tłumaczenie za pomocą ekwiwalentu funkcjonalnego nie jest rażącym błędem, jednakże można było wykorzystać naukowe odpowiedniki funkcjonujące w terminologii weterynaryjnej. Takie rozwiązanie w pełni oddałoby znaczenie terminu rosyjskiego, a nie tylko pewną jego część.

W obrębie badanego tekstu w przypadku tłumaczenia nazw chorób zwierząt stosowanie w miarę konsekwentnie techniki uznanego ekwiwalentu, jest zabiegiem w pełni zrozumiałym. Wykorzystane uznane odpowiedniki nie budzą w danych przypadkach zastrzeżeń, tym bardziej, że zarówno nazwy chorób $\mathrm{w}$ języku rosyjskim jak ich odpowiedniki w języku polskim są w większości przypadków zapożyczeniami z języka łacińskiego tego samego terminu:

Лептоспироз
Губкообразная энцефалопатия
$\quad$ крупного рогатого скота
Инфекционный ринотрахеит
Меди-висна
Нодклярный дерматит
Лейкоз
Инфекционная агалактия

Инфекционная агалактия

$$
\text { - leptospiroza }
$$

- gąbczasta encefalopatia bydła

- zakaźne zapalenie nosa i tchawicy

- choroba Maedi-Visna

- choroba guzowata skóry

- białaczka

- zakaźna bezmleczność 
Инфекционный мастит Инфекционный эпидидимит Африканская чума свиней Везикулярная болезнь свиней Классическая чума свиней Трхинелез Энцефаломиелит

Чума лошадей
- zakaźne zapalenie wymienia

- zakaźne zapalenie najądrza

- afrykański pomór świń

- choroba pęcherzykowa świń

- klasyczny pomór świń

- włośnica

- zakaźne zapalenie mózgu i rdzenia

- pomór koni

W wyniku analizy ekwiwalentów chorób zwierzęcych odnotowano także występowanie kilku odpowiedników odnoszących się do jednej choroby, spośród których tłumacz wybiera jeden i stosuje go systematycznie na przestrzeni całego tekstu:

Скрейпи овеи. Nazwa owej choroby jest typowym zapożyczeniem z języka angielskiego od słowa scrapie co oznacza ocierać się. W przekładzie użyto jednego $\mathrm{z}$ dwóch odpowiedników funkcjonujących $\mathrm{w}$ nauce z czego użyty trzęsawka jest określeniem potocznym, a typowa naukowa nazwa to choroba kłusowa lub kołowacizna.

Чума мелкого рогатого скота w polskiej literaturze przedmiotu oprócz wybranego przez tłumacza wariantu pomór małych przeżuwaczy funkcjonują następujące określenia powyższej choroby: księgosusz rzekomy, zespót zapalenia jamy ustnej, płuc i jelit.

Бруцеллез. W danym przypadku tłumacz używa podstawowej nazwy zapożyczonej z języka łacińskiego bruceloza. W polskiej literaturze przedmiotu funkcjonuje także nazwa ronienie zakaźne.

Ящyp. W obrębie badanego tekstu jest używany odpowiednik pryszczyca. Jednakże w literaturze fachowej można spotkać nazwę tej choroby świń. Jest nią zaraza pyska $i$ racic, która została zapożyczona $\mathrm{z}$ języka angielskiego od foot and mouth disease (FMD).

Трихомоноз. W danym przypadku tłumacz stosuje wariant zaraza rzęsistkowa bydła. W literaturze równie często można spotkać nazwę rzęsistkowica.

Болезнь Ауески. W tekście jest używany wariant choroba Aujeszkiego. Można także spotkać nazwę wścieklizna rzekoma.

Кампылобактериоза jest tłumaczona jako kampylobakterioza. W polskiej literaturze fachowej równie często w odniesieniu do tej choroby jest spotykany termin choroba mętwikowa bydła.

Блутанг. Rosyjska nazwa tej choroby jest zapożyczeniem z języka angielskiego od blue tongue. Dla danego terminu wybrano wariant 
choroba niebieskiego języka. W polskiej literaturze funkcjonuje także pryszczyca rzekoma.

Odnotowano także przypadki, że tłumacz stosuje istniejące odpowiedniki naprzemiennie w badanym tekście:

Хламидиоз w obrębie badanego tekstu jest tłumaczona zarówno jako chlamydioza, jak i epizootyczne ronienie bydła.

Analizując tekst, zaobserwowano także stosowanie w przekładzie niepełnych nazw chorób zwierzęcych. Вирусная диарея крупного рогатого скота została przetłumaczona jako wirusowa biegunka bydła, gdzie w obiegu funkcjonują następujące pełne nazwy choroby: wirusowa biegunka bydła $i$ choroba błon śluzowych lub BVD/MD z języka angielskiego Bovine Viral Diarrhea-Mucosal Disease. Innym przypadkiem jest везикулярный стоматит tłumaczony jako zapalenie pęcherzykowe, gdzie pełna nazwa owej choroby brzmi pęcherzykowe zapalenie jamy ustnej. Jednakże w tym przypadku w dalszej części badanego tekstu tłumacz używa pełnej nazwy. Należy mieć na uwadze, iż skracanie niektórych terminów zwłaszcza medycznych może prowadzić do pewnych niedomówień w tekście dokumentu.

Odnotowano także przypadki tłumaczenia dosłownego mimo, iż w obiegu funkcjonuje uznany, odmienny od zaproponowanego, odpowiednik nazwy choroby. Dotyczy to terminu заразный узелковый дерматит przetłumaczonego jako zakaźne węzetkowe zapalenie skóry. W tym przypadku uznany odpowiednik zastosowano tylko do jednego członu terminu tj. дерматит, natomiast pozostałe elementy terminu zostały przetłumaczone dosłownie. Prawidłowym odpowiednikiem polskim jest choroba guzowata skóry. Tłumacz tymczasem stosował prawidłowy odpowiednik w odniesieniu do synonimicznych rosyjskich nazw choroby, tj. нодулярный дерматит.

Wśród badanych jednostek jednokrotnie zastosowano technikę hiperonimu podczas tłumaczenia nazwy choroby cyppa jako trypanosomoza. Zastosowana tutaj technika hiperonimu polega w tym przypadku na tym, iż nazwę w języku rosyjskim oznaczającą konkretny typ choroby zastąpiono nazwą znaczeniowo szerszą obejmującą kilka chorób pasożytniczych, w skład których wchodzi m.in. właśnie ta przetłumaczona. W celu prawidłowego zrozumienia poniżej zostaną przytoczone definicje. Otóż, trypanosomoza to nazwa dla kilku chorób pasożytniczych wywoływanych przez świdrowce. W analizowanej dziedzinie weterynarii pod daną nazwą należy rozumieć między innymi następujące typy trypanosomozy: nagana, surra, dourine, baleri i inne. Tłumaczona $\mathrm{w}$ danym przypadku cyppa posiada w języku polskim swój odpowiednik w postaci „surra” i odnosi się do typu trypanosomozy występującej u koni, bydła, wielbłądów. $\mathrm{W}$ związku z powyższym można było zastosować odpowiednik surra w celu 
uniknięcia szerszego kontekstu znaczeniowego a sprecyzowania wspomnianej w tekście oryginału zwierzęcej choroby śmiertelnej.

Z powyższej analizy rosyjskich nazw chorób zwierzęcych można zaobserwować, iż zarówno terminy rosyjskie, jak i ich uznane odpowiedniki polskie zostały zapożyczone przede wszystkim z języka łacińskiego, w mniejszym stopniu z języka angielskiego, co ułatwia zastosowanie techniki odpowiednika uznanego, która okazała się w badanym tekście dominującą. Dzięki owej technice otrzymuje się tekst jednoznaczny i precyzyjny. Język rosyjski dysponuje większą ilością nazw chorób zapożyczonych, aniżeli język polski. Zaobserwowano przypadki, gdzie dla terminu rosyjskiego, który jest wyraźnym zapożyczeniem $\mathrm{z}$ języka łacińskiego, zaproponowano odpowiednik polski, powstały wyłącznie na bazie własnych środków językowych. Mała różnorodność stosowanych przez tłumacza technik tłumaczeniowych wydaje się uzasadniona w odniesieniu do typu danego tekstu. Dominująca technika odpowiednika uznanego pozwoliła stworzyć tekst w pełni jednoznaczny i zrozumiały dla specjalistów pracujących na podstawie przepisów w nim zawartych. Wszelkie próby stosowania innych technik tłumaczeniowych okazywały się zawodne i prowadziły do zatarcia znaczenia danej nazwy choroby bądź do jej zdeformowania. Trudno jednoznacznie stwierdzić czy użycie innych technik tłumaczeniowych było świadomym zabiegiem tłumacza, czy też wynikało z jego niewiedzy lub błędów.

\section{Bibliografia}

Dyrektywa Rady 93/119/WE z dnia 22 grudnia 1993 r. w sprawie ochrony zwierzat podczas uboju lub zabijania, [online], https://publications.europa.eu/pl/publication-detail/-/publication/3282c5bf-3613-486c-a875-2647c52614ce/language-pl, [dostęp: 26.08.2018].

Dyrektywa Rady z dnia 26 czerwca 1964 r.w sprawie problemów zdrowotnych zwierząt wpływających na handel wewnątrzwspólnotowy bydłem i trzoda chlewną. (64/432/EWG), [online], http://webcache.googleusercontent.com/search?q=cache: LuFyUANyzLsJ:orka.sejm.gov.pl/Drektywy.nsf/all/31964L0432/\%24File/31964 L0432.pdf $+\& \mathrm{~cd}=5 \& \mathrm{hl}=\mathrm{pl} \& \mathrm{ct}=\mathrm{clnk} \& \mathrm{gl}=\mathrm{pl}$, [dostęp: 26.08 .2018$]$.

Kizińska A., Ekwiwalencja w tłumaczeniu tekstów prawnych i prawniczych. Polskie i brytyjskie prawo spadkowe, Warszawa 2015.

Kubacki A.D., Jak tłumaczyć oficjalne nazwy zawodów i specjalności z języka niemieckiego i na język niemiecki?, [w:] Język a komunikacja 26. Tłumacz wobec problemów kulturowych, M. Piotrowska (red.), Kraków 2010, s. 71-81.

Rozporzadzenie Rady (WE) nr 1/2005 z dnia 22 grudnia 2004 r. w sprawie ochrony zwierzat podczas transportu $i$ zwiazanych $z$ tym działań oraz zmieniajace dyrektywy 64/432/EWG i 93/119/WE oraz rozporzadzenie (WE) nr 1255/97, 
[online], https://eur-lex.europa.eu/legal-content/PL/ALL/?uri=CELEX\%3A 32005R0001, [dostęp: 26.08.2018].

Rozporzadzenie Rady (WE) nr 1255/97 z dnia 25 czerwca 1997 r. dotyczace kryteriów wspólnotowych dla miejsc postoju, [online], https://webcache.googleusercontent. $\mathrm{com} /$ search?q=cache:VeFfFCvzi98J:https://publications.europa.eu/pl/publication-de tail/-/publication/c9ac2f76-604b-45c8-91f8-14a08ab8d71b/language-pl+\&cd=1\&h$\mathrm{l}=\mathrm{pl} \& \mathrm{ct}=\mathrm{clnk} \& \mathrm{gl}=\mathrm{pl}$, [dostęp: 26.08.2018].

Ustawa z dnia 11 marca 2004 r. o ochronie zdrowia zwierząt oraz zwalczaniu chorób zakaźnych zwierzat (Dz. U. $2004 \mathrm{nr} 69$ poz. 625).

Ustawa z dnia 29 stycznia 2004 roku o Inspekcji Weterynaryjnej (Dz. U. $2004 \mathrm{nr} 33$ poz. 287).

Załacznik nr 2 WYKAZ CHORÓB ZAKAŹNYCH ZWIERZĄT PODLEGAJĄCYCH OBOWIĄZKOWI ZWALCZANIA (Dz.U.2008.213.1342), [online], https://webcache.googleusercontent.com/search?q=cache:8G9id5WTDUcJ:https://piwstar.bip.gov.pl/fobjects/ download/29061/wykaz_chorob-pdf.html+\&cd=3\&hl=pl\&ct=clnk\&gl=pl, [dostęp: 26.08.2018].

Zaniewski J., Hajczuk R., Podręczny słownik medyczny polsko-rosyjski i rosyjsko-polski, Warszawa 2006.

Решение Комиссии таможенного союза ЕврАзЭС от 18 июня 2010 г. № 317 «О применени ветеринарно-санитарных мер в таможенном союзе», [online], http:// www.tsouz.ru/KTS/KTS17/Pages/R_317.aspx, [dostęp: 26.08.2018]. 